\title{
A MODERN NESTING RECORD FOR WHOOPING CRANES IN ALBERTA
}

ERNIE KUYT, Canadian Wildlife Service, 9942 - 108 St., Edmonton, Alberta T5K 2J 5

The former breeding range of the Whooping Crane extended in a long, narrow band from Illinois in the southeast to the east-central portion of Alberta. The last U. S. nest was found in lowa in 1894 and the last Canadian breeding record was the 1922 nest at Muddy Lake, Saskatchewan. Prior to this, the last Alberta Whooping Crane nest was found in 1914 near Wainwright. ${ }^{\prime}$

Porter lists two Northwest Territories' nests, located in the area between Salt River and Fort Resolution and dating back to 1864 . It was about $40 \mathrm{~km}$ west of a line connecting these two communities where the last remaining Whooping Crane breeding area was discovered in $1954 .^{2}$

From 1954 to 1965 up to six breeding airs were accounted for annually in he Sass River area, the only portion of he breeding range regularly surveyed. ${ }^{3}$ rom 1966 to the present, the total umber of known breeding pairs has ncreased because of more intensive erial surveying because additional airs were discovered in areas other han near Sass River and because of a low increase in the breeding opulation. ${ }^{4}$

The wild whooper flock migrating rom the N.W.T. to Texas has increased rom 21 birds in 1954 to about 70 birds t present. This is due, in part, to (1) atisfactory environmental conditions f summer and winter ranges, (2) rigid rotection of the cranes throughout peir migration pathway, and (3) panagement techniques which have sulted in greater survival of young in the wild during years when eggs were collected from N.W.T. nests than in non-collecting years. ${ }^{4}$

The last of 17 Whooping Crane nests found in 1977 was discovered on May 9, during an aerial search over potential nesting habitat $30 \mathrm{~km}$ south of the Sass River area. Up to that time I had never seen whoopers there before, but the marshes appear suitable and are checked several times each spring.

Scrutiny of our maps showed that the nest was about five $\mathrm{km}$ south of the 60th parallel. It marks the first time in 63 years that, at least to my knowledge, Whooping Cranes have nested in Alberta.

The nest contained two eggs, one of which was removed on May 20, 1977 along with single eggs from 15 other nests. The remaining egg in nest No. 17 hatched on or about June 3 , the last egg to hatch in the north in 1977

The second egg was flown to Idaho, where it was placed in the nest of a Greater Sandhill Crane on May 21, and hatched on June 2, the last whooper egg to hatch at Gray's Lake in 1977 (R. Drewien, pers. comm.). This young fledged successfully and migrated with its foster-parents to New Mexico.

Taking into consideration a 29-day incubation period (Kuyt, unpubl. data), the eggs would have been laid about May 4-5. The nest was $130 \mathrm{~cm}$ across and $20 \mathrm{~cm}$ thick on May 20. Nest material was chiefly the dead stalks of bulrush (Scirpus sp.) on a base of Scirpus rootstocks with adhering mud. The depth of the pond at one meter 


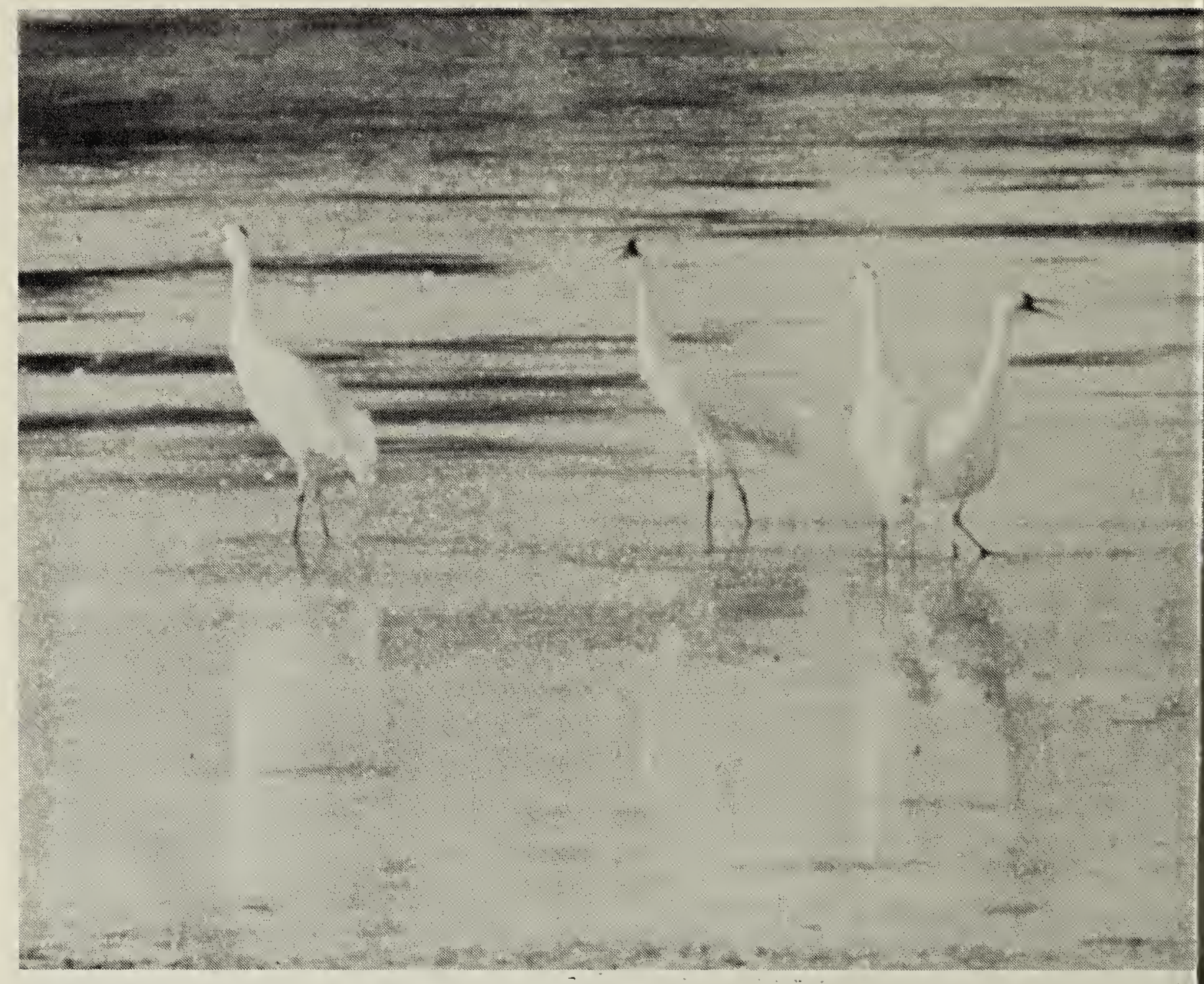

Whooping cranes at Lucky Lake, Saskatchewan

Gary W. Se

distance from the nest was $24 \mathrm{~cm}$.

As with most Whooping Crane nests, this one was located in a rather shallow marsh with bulrush and sedge (Carex sp.) the dominant plants. The marsh was surrounded by trees, chief of which were black spruce (Picea mariana), white spruce ( $P$. glauca), tamarack (Larix laricina), white birch (Betula papyrifera) and trembling aspen (Populus tremuloides). Several shrubs dotted the nest marsh, particularly in shallow parts, and a few willows (Salix sp.) and dwarf birch (Betula glandulosa) grew near the nest.

Although the Alberta nest found in 1977 is about $25 \mathrm{~km}$ south of the nearest nest along Sass River, the location is well within Wood Buffalo National Park and the new nesting pair should benefit from the same protection afforded by the Park as other nesting Whooping Cranes.

'ALLEN, R. P. 1952. The Whooping Cran Nat. Audubon Soc., Res. Rep. \#3. Ne York. 246 pp.

${ }^{2}$ ALLEN, R. P. 1956. The Whooping Crane northern breeding grounds. Suppleme to Nat. Audubon Soc. Res. Rep. \#3. Ne York. 60 pp.

${ }^{3}$ NOVAKOWSKI, N. W. 1966. Whoopi Crane population dynamics on $t$ nesting grounds, Wood Buffalo Nation Park, Northwest Territories, Canac Can. Wildl. Ser. Rep. Ser. No. 1. Queer Printer, Ottawa. 20 pp.

${ }^{4}$ KUYT, E. 1978. Nest site fideli productivity and breeding habitat Whooping Cranes, Wood Buffa National Park, Northwest Territori Canada. In Crane research round $t$ world. Int. Crane Foundation, Baribc Wisc. in press. 
